\title{
The Canadian Tuckahoe
}

\section{By T. C. Vanterpool, Professor of Plant Pathology, University of Saskatchewan}

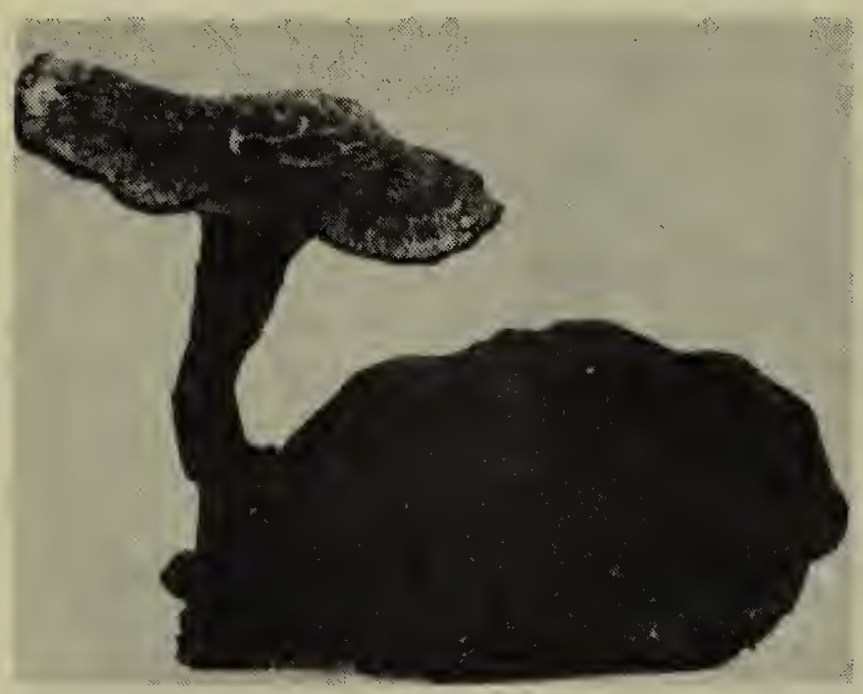

D you know the Canadian Tuckahoe? It is the large black storage body or resting stage of the mushroom-like fungus Polyporus tuberaster (see figures). The tuckahoe is found in the black soil of the park belt where the aspen flourishes. Collections have been made as far south as the Pembina Hills in Manitoba and in a rough line extending northwestward through Saskatchewan and Alberta to 70 miles north of Kamloops, B.C.

A few specimens are received at the University every year from the parkland belt where virgin land covered with poplar groves is being cleared and brought under the plough. Many of them come from school teachers to whom they have been brought by curious children. They are sometimes referred to as "Indian bread" or are wrongly mistaken for pemmican or dried buffalo meat of the Indians, but even the softest are much too tough to be eaten and do not soften appreciably when boiled. One very young specimen was soft when received and it is just possible that in such a condition they may have been eaten, though there is no record that this is so. However, they do appear to have been used by the Indians for poulticing and for rheumatism and were called "grcund medicine" by them.

The bodies are spherical to oval and occasionally slightly flattened. They are of a hard, rubbery consistency when fresh but dry out to the hardness of a stone. Such dry specimens will absorb about 50 per cent of their weight of water. They vary in size from about 2 to 8 inches in diameter, and the largest may weigh between 8 and 9 pounds.

The mushroom-like growths to

The Canadian Tuckahoe, a fungus storage body-not pemmican. The top figure shows a tuckahoe and a mushroom-like fruiting structure to which it has given rise. The centre figure shows a surface view, and the bottom figure an internal view of a tuckahoe.

which the tuckahoes give rise vary from 23 to 6 inches in diameter and from 2 to 5 inches in height. These structures are not edible. They may be obtained by burying fresh tuckahoes from one to three inches below ground level either directly in poplar groves or in pots of soil buried level 
with the ground and kept moist. Tuckahoes, collected in May and buried immediately, often produced the fruiting structures ("mushrooms") the same year in late June or early July, ivut more often the fruit bodies are not produced until the following summer. Sometimes more than one fruit body may be attached to a single tuckahoe; also a single tuckahoe may produce fruit bodies several years in. succession. It is believed that the tuckahoes grow in association with the roots of the aspen, but conclusive evidence on this point is lacking. A careful search in poplar bluffs in northern Saskatchewan during early July might reveal some of these fruit bodies which have tiny pores or holes under the cap instead of gills, as in the common mushroom. If one digs beneath the fruit bodies one might be rewarded by finding the tuckahoe to which they are attached.

NOTE:-Anyone requiring further technical information on the tuckahoe should consult a paper by T. C. Vanterpool and Ruth Macrae in the Canadian Journal of Botany, 29; 147-157. 1951.

\section{The Naturalist's Library}

FLORA OF MONTANA. Part 1, Conifers and Monocots. By E. W. Booth, Montana State College, Bozeman, Montana, 1950, pp. 232, illustrated with 83 figures. $\$ 3.00$. Keys and descriptions of the species are given.

WILD FLOWERS IN THE ROCKIES. By G. A. and W. V. Hardy. H. R. Larson Publishing Co., Hamilton, Saskatoon and Vancouver, 1949 , pp. 125 , illustrating in color 200 wild flowers occurring in the Canadian Rockies. $\$ 7.50$.

NATIVE ORCHIDS OF NORTH AMERICA. By D. S. Corell, Chronica Botanica Company, Waltham, Mass., 1950, pp. 399,146 plates in superb line drawings. $\$ 7.50$.

NATIVE TREES OF CANADA. Dept. Mines and Resources, Dominion Forest Service, Ottawa. Bull. 64, 4th ed., reprinted 1950, pp. 293. Profusely illustrated, including range maps and a Forest Classification Map of Canada. $\$ 1.50$.

WILD VIOLETS OF NORTH AMERICA. By Viola Brainerd Baird. University of California Press, Berkeley and Los Angeles, 1942, pp. 225, 77 color illustrations by $F$. S. Mathews. $\$ 10.00$. This book endeavours tc provide those interested in violets with a simple means of identifying the different species.
BOTANY OF SOUTHEASTERN YUKON. By A. E. Porsild. Dept. Resources and Development, Nat. Mus. Canada, Ottawa, 1951, pp. 400. \$1.00. Describes the vegetation of the region including an annotated catalogue of the vascular plants of Yukon, totaling 894 species. Of this number 28 are new or recently described species.

A GUIDE TO BIRD SONGS. By A. A. Saunders. Doubleday \& Co., Inc., Garden City, New York, 1951, pp. 307. \$3.00. This book is by one of America's leading authorities and is the most complete and comprehensive volume on American bird songs ever published iricluding over 200 diagrams by the author.

AUDUBON'S BIRDS OF AMERICA. MacMillan Co., New York, 1950, pp. 320. \$3.95. Illustrated with 288 magnificent full page color plates. Each plate is accompanied by a concise descriptive text. Audubon bird painting are unsurpassed in the century following the artist naturalist's death in 1851.

THE INSECT GUIDE. By $R$. B. Swain. Doubleday \& Co., Inc., Garden City, New York, 1949, pp. 261, over 450 illustrations, many in color, representing 251 different insect species in the United States and Canada. $\$ 3.50$. 